\title{
Telecommunications Liberalization and Regulatory Governance: Lessons from Latin America
}

\author{
By Luis H. Gutiérrez and Sanford Berg* \\ Public Utility Research Center, University of Florida
}

Executive Summary

The role of the state changed in Latin American and Caribbean countries between 1985 and 1995 as eight regulatory commissions were created (for the nineteen countries in our regional sample). This institutional innovation was part of the liberalization process that has permeated the hemisphere. This study examines the determinants of telephone lines per capita, using economic, institutional and regulatory variables. Lacking information on total investment, we use lines as a proxy for telecommunications investment. The economic variables have the expected impacts. Gross Domestic Product (GDP) per capita affects investment in a positive way: telecommunications services are income-elastic. Openness (exports plus imports as a percentage of GDP) captures significant external links which require telecommunications to coordinate the production and delivery of goods and services. This variable had a positive (but not statistically significant) impact. Similarly, greater population density was a significant determinant of lines per capita for this particular sample of countries (reflecting lower cost of service for urban areas).

Building on the work of Levy and Spiller (1996), we introduce institutional indices to capture the effects of political democracy, economic freedom, and a sound regulatory framework. The latter captures the degree of independence of the regulatory body, enforcement powers, neutrality, and mechanisms for resolving conflicts. It might be viewed as a proxy for serious reform initiatives (including reduction of entry barriers and privatization). The regulatory framework and freedom factors have significant positive impacts on telephone lines per capita. Another important explanatory variable is the number of cellular phones per capita. The positive impact is consistent with cellular being a complement for fixed line telephony. Alternatively, the positive impact could reflect a "competition effect" whereby competitive entrants in a liberalized sector stimulate improved performance (and additional investment) by incumbent wire-line firms.

* The authors are Research Associate and Director, respectively, at the Public Utility Research Center, University of Florida. Helpful comments by David Sappington, Mark Jamison, and an unidentified referee are gratefully acknowledged. An earlier version of this paper was presented at a Conference on Privatization, Deregulation and Institutional Framework sponsored by the Institute of Developing Economies, Tokyo, December 7-8, 1998. 


\section{Introduction}

In the last two decades, the improvement in communications technology has been explosive. Fiberoptics cables have replaced microwave circuits in long distance transmission; telephone-switching systems are more sophisticated, allowing a wider variety of call transfer, message storing, and control functions. Cellular and mobile telephony have expanded at accelerating rates in recent years, and the development of private networks has also been remarkable. Parallel to these new developments, there has been a pattern of increasing competition in the provision of valued-added services, long distance telecommunications, and, more recently, in local telephony (see Hudson 1997).

The present study is part of a project ${ }^{1}$ examining the evolution of telecommunications investment in nineteen Latin and Caribbean countries. Its goal is to determine the economic, demographic, institutional and regulatory factors that may have contributed to the development of the sector. Although many studies analyze past trends and the determinants of the investment and economic growth in this geographic area, ${ }^{2}$ this is the first study that addresses the potential impact of a sound regulatory framework on the level of investment in telecommunications in the region. ${ }^{3}$

We found that institutional factors have a significant and positive impact on the deployment of telephone main lines. As expected, the GDP per capita was also significant. A variable that captures the degree of economic freedom is another significant determinant of teledensity. Lastly, the number of cellular subscribers has a positive impact on lines per 100 inhabitants, either suggesting a complementary relation with fixed telephony or reflecting the effect of competitive pressure. Both economic and institutional factors are important determinants of telecommunications investment. The results are

\footnotetext{
${ }^{1}$ See chapters 2 and 3 of Gutierrez's (1999) doctoral dissertation.

${ }^{2}$ See, among others, Campos and Nugent (1998), Easterly et al. (1997), Pastor and Hilt (1993), Lora and Barrera (1997), Lora (1998), Fernandez-Arias and Montiel (1997), and IADB (1997).

${ }^{3}$ Teledensity or penetration rate as a measure of total main lines per 100 hundred inhabitants is the proxy for investment. Our focus is primarily on basic telecommunications services, i.e., fixed and long distance telephony. As will be discussed
} 
consistent with Levy and Spiller's conclusion that, for countries in which governments do not commit to maintaining a credible and independent regulatory framework, there will tend to be under-investment in infrastructure. Of course, we recognize that much work remains on fully sorting out the factors influencing the decision to reform (or set up an independent regulatory commission). For example, we would expect reform also to be driven by the actions and performance of neighboring countries, the decision to abide by WTO agreements, and the financial sustainability of government investments in the sector.

After outlining policy developments, this paper summarizes recent empirical research. Then the study describes the data sample, defines the variables used in this empirical analysis, and interprets the estimated coefficients in terms of their impacts on telecommunications investment. The last section contains concluding observations.

\section{Patterns in Latin America and the Caribbean}

The financial requirements for the modernization and expansion of public telecommunications networks are substantial. Telecommunications operators all over the world, but especially in Latin America, used to be state-owned companies. The adoption of new technologies lagged from lack of autonomy, constraints on financial resources, poor managerial and technical expertise, and inappropriate incentives. In the 1980s, when a debt crisis hit most Latin American countries, many had large fiscal deficits, high inflation, and a perceived risk of political instability that limited their ability to obtain capital for financing public telecommunications networks. In the 1990s, privatization or the selling of the majority of shares of their telecommunications operators (telcos) has been the route to system modernization and expansion (see Pisciotta 1997, Wellenius 1999, and ITU 1997b).

Between 1984 and 1997, fourteen out of twenty-four Latin and Caribbean countries privatized their former stated-owned telcos, either totally or partially, for an estimated value of U.S. \$27 billion (ITU 1997b). ${ }^{4}$

later, other studies have examined privatization, rate re-balancing, and systems of checks and balances.

${ }^{4} \mathrm{~A}$ large number of researchers have analyzed public policies and telecommunications sector performances in 
And this amount is greater if we include Brazil, the giant of Latin American telecommunications that recently privatized the Telebras system. Other smaller countries of the region may follow this trend. Along with the privatization surge that is transforming outdated technological networks is the recognition that a modern regulatory framework is needed to cope with the new challenges that greater competition and innovation bring to the telecommunications arena. So most of the countries in the region have enacted new laws that make the rules of the game more transparent and credible to potential investors.

However, as Latin American countries have reopened their markets to foreign investment for the deployment of the telecommunications infrastructure, investors have become more concerned about the political and institutional factors affecting risks and returns. For fixed wire-line technologies, large sunk investments in telecommunications facilities expose suppliers of capital to greater expropriation risk via government opportunism

The privatization process in the region reflects tradeoffs that governments were willing to make early on to lure foreign investors and assure their ability to earn adequate returns. As shown in Table 1, governments involved in the initial privatization efforts offered substantial benefits, the most important of which was exclusivity in the provision of services. These concessions were reasonable at the time; however, it is clear that countries engaged in later or ongoing privatization do not offer such exclusivity, having learned from the experience of others. ${ }^{5}$

\section{Table 1. Liberalization Timetable}

\begin{tabular}{|l|c|c|c|c|c|c|c|c|c|}
\hline \multicolumn{1}{|c|}{ Main Basic Telecommunications Services. } \\
\hline Country & $1994-1996$ & 1997 & 1998 & 1999 & 2000 & 2001 & 2002 & 2003 & $2010-$ on \\
\hline Chile & xoxoxoxo & xoxoxo & xoxoxo & xoxoxo & xoxoxo & xoxoxo & xoxoxo & xoxoxo & xoxoxo \\
\hline Colombia & xxxxxxx & xxxxxx & xoxoxo & xoxoxo & xoxoxo & xoxoxo & xoxoxo & xoxoxo & xoxoxo \\
\hline
\end{tabular}

individual countries; see, for example, Gonzalez et al. (1998) and McCormick (1993).

${ }^{5}$ For a criticism of the way privatization was implemented in developing countries, see Stiglitz (1998) and Wellenius (1999). 


\begin{tabular}{|c|c|c|c|c|c|c|c|c|}
\hline Mexico & xoxoxo & xoxoxo & xoxoxo & xoxoxo & xохохо & xoxoxo & xoxoxo & xoxoxo \\
\hline Peru & & xoxoxo & xoxoxo & xoxoxo & xoxoxo & xoxoxo & xoxoxo & xoxoxo \\
\hline El Salvador & & & xoxoxo & xохохо & xoxoxo & xoxoxo & xoxoxo & xoxoxo \\
\hline Guatemala & & & xoxoxo & хохохо & xохохо & хохохо & xoxoxo & хохохо \\
\hline Argentina & & & & xохохо & xохохо & xoxoxo & xoxoxo & xoxoxo \\
\hline Venezuela & & & & xохохо & xохохо & хохохо & xoxoxo & xoxoxo \\
\hline Brazil & & & & xохохо & xoxoxo & xoxoxo & xoxoxo & xoxoxo \\
\hline Ecuador & & & & xохохо & xoxoxo & xохохо & xoxoxo & xoxoxo \\
\hline Bolivia & & & & & xoxoxo & xoxoxo & xoxoxo & xoxoxo \\
\hline Panama & & & & & & & xoxoxo & xoxoxo \\
\hline $\begin{array}{l}\text { Trinidad } \\
\text { and } \\
\text { Tobago*/ }\end{array}$ & & & & & & & & oxoxo \\
\hline Jamaica*/ & & & & & & & & хохохо \\
\hline Nicaragua & & & & & & & & NDT \\
\hline Honduras & & & & & & & & NDT \\
\hline Costa Rica & & & & & & & & NDT \\
\hline Paraguay & & & & & & & & NDT \\
\hline Uruguay & & & & & & & & NDT \\
\hline
\end{tabular}

Source: ITU (1998) and author compilation

o represents long distance service and $\mathrm{x}$ local telephony.

NDT: Not determined yet.

*/ Currently these countries are in talks to open their markets earlier than agreed.

Why was the Latin American market so attractive to investors, given the difficult decade of debt problems, high inflation, and high country-risk ratings of the early 1980s? Many factors, including the return of democracy, can explain the renewal of interest in the region. As shown in Table 2, the average indicator of democracy for the region increased from 1.42 in the second part of the 1980 s to 2.03 in the first half of the 1990s (the derivation of these numbers is described in the Appendix). With the exception of Peru, all the countries included in Table 2 experienced movements toward democracy.

The associated economic progress has been limited. GDP per capita grew from U.S. \$2,062 to U.S. $\$ 2,186$ (in 1990 dollars), an increase of only $6.01 \%$ in ten years (for more about this, see Fernandez-Arias and Montiel 1997 and IADB 1997). Nevertheless, the improved aggregate economic performance of the region began to affect the country-risk evaluations made by international investors. Three well-known indicators described in the Appendix - Euromoney, Institutional Investors and ICRG (International Country Risk Guide) show remarkable improvements in the country evaluations (see Table 2). 
Table 2. Economic, Political and Demographic Indicators in Latin America

\begin{tabular}{|l|c|c|}
\hline 19 Latin and Caribbean Countries* & $1986-1990$ & $1991-1995$ \\
\hline GDP per Capita (US\$1990) & 2,062 & 2,186 \\
\hline Growth of GDP per capita & .03 & 1.88 \\
\hline Democracy-GOVTYPE & 1.42 & 2.03 \\
\hline Euromoney & 32.27 & 41.68 \\
\hline Institutional Investor & 22.30 & 26.64 \\
\hline ICRG & 2.28 & 2.51 \\
\hline Structural Policy Index (IADB) & .425 & .581 \\
\hline Economic Freedom Index & 4.75 & 5.52 \\
\hline Population density & 33.96 & 38.29 \\
\hline Urban Population & 62.10 & 64.73 \\
\hline Trade (Exports+Imports)/GDP & 51.16 & 63.32 \\
\hline Cellular Subscribers per 100 inhabitants & 0.01 & 0.31 \\
\hline Main Lines per 100 inhabitants & 5.43 & 7.68 \\
\hline
\end{tabular}

* These are Argentina, Bolivia, Brazil, Chile, Colombia, Costa Rica, Ecuador, El Salvador, Guatemala, Honduras, Jamaica, Mexico, Nicaragua, Panama, Paraguay, Peru, Trinidad and Tobago, Uruguay and Venezuela. See the Appendix for a description of the variables and their source.

Parallel to the better positioning of the region in the country-risk indices, most of the governments promoted economic reforms that made significant economic progress possible. The extent of the reforms can be evaluated in terms of the Structural Policy Index, created by researchers at the Inter-American Development Bank, and by the Economic Freedom Index. In both it is clear that the region has moved toward greater dependence on market mechanisms and less on the national government.

\section{Theoretical Background and Hypothesis}

State-owned companies controlled public utilities, including the telecommunications sector, in most Latin American countries for decades. Many factors contributed to that pattern. First, given the large scale of investment necessary, the absence of broad national capital markets made it difficult to obtain funds for 
capacity expansion and modernization. Second, national security and defense arguments that it was not appropriate for such important industries to be controlled by foreign interests were advanced. ${ }^{6}$ Third, there were political reasons to maintain control over the provision of the output because, by controlling them, governments could avoid unpopular increases in the tariffs. Lastly, in some countries, foreign investment was believed to be harmful, or at least undesirable, to economic growth (Noll 1999).

Other reasons might be viewed as equally compelling. ${ }^{7}$ Given the scale of investment and its idiosyncratic nature in public utilities, governments were often seen by foreign investors as opportunistic partners (see Williamson 1975, Levy and Spiller 1996). Once the telecommunications investment is completed (or sunk), it cannot be allocated easily to alternative uses. Given that those services are viewed as "necessities" and involved monopoly production, government control over the final prices was viewed as crucial. Therefore, foreign investors avoided public utilities industries because of the likelihood of this kind of takings (an implicit, rather than explicit, form of expropriation).

To mitigate or eliminate this problem, strong regulatory governance is needed. The presence of a regulatory institution insulated from short-term political pressure has the effect of reducing investors' risks and increasing their confidence in a nation's governance. A formal institution enhances private (domestic as well as foreign) investment in utilities (see Smith and Wellenius 1999). Hence, we posit that countries with sound economic institutions and stable political systems (polity) will reduce investors' risks, increase confidence in government policies and expand the level of investment in utilities.

\section{Telecommunications Reform}

As the last row of Table 2 shows, the number of main phone lines per 100 inhabitants increased about 41\%, from five to almost eight lines per 100 inhabitants. Hence, as Latin American countries strengthen their political systems, become more integrated into the world economy, and look more attractive to foreign

\footnotetext{
${ }^{6}$ This was the case of the change to public ownership for the Union Telefonica in Argentina in 1946 (see Petrazzini 1996). Melody (1997) explains state ownership in response to such concerns.

${ }^{7}$ Levy and Spiller (1996) explain this position in detail. Also see Spiller (1993).
} 
investors, there is a parallel increase in investment in telecommunications. Privitization also mattered.

Table 3. Comparisons of Pre- and Post- Privatization Reform $\nabla /$

\begin{tabular}{|c|c|c|c|}
\hline \multicolumn{4}{|c|}{ Countries that privatized their former state-owned operators $\diamond /$} \\
\hline & $\begin{array}{c}\text { Year*/ of } \\
\text { Privatization }\end{array}$ & $\begin{array}{l}\% \text { Annual Growth } \\
\text { Prior to Privatization }\end{array}$ & $\begin{array}{c}\% \text { Annual Growth From } \\
\text { Privatization }\end{array}$ \\
\hline Trinidad \& Tobago & 1990 & 15.0 & 5.0 \\
\hline Belize & 1988 & 12.1 & 9.5 \\
\hline Barbados & 1989 & 6.7 & 6.4 \\
\hline Chile & 1987 & 5.7 & 13.7 \\
\hline Argentina & 1990 & 5.2 & 8.2 \\
\hline Mexico & 1991 & 5.1 & 5.6 \\
\hline Jamaica & 1989 & 5.0 & 16.6 \\
\hline Peru & 1994 & 4.2 & 23.7 \\
\hline Venezuela & 1991 & 3.8 & 6.8 \\
\hline Bolivia & 1995 & 2.4 & 29.0 \\
\hline Guyana & 1991 & -2.4 & 24.1 \\
\hline Simple Average & & 5.7 & $\mathbf{1 3 . 5}$ \\
\hline \multicolumn{4}{|c|}{ Countries that did not privatize their former state-owned operators } \\
\hline & & \multicolumn{2}{|c|}{ \%Annual Average Growth Rate } \\
\hline & & $1981-1989$ & 1990-1997 \\
\hline Honduras & & 8.5 & 10.6 \\
\hline Suriname & & 8.3 & 6.9 \\
\hline Colombia & & 5.8 & 10.6 \\
\hline Uruguay & & 5.5 & 8.4 \\
\hline Ecuador & & 5.5 & 6.6 \\
\hline Paraguay & & 5.1 & 7.3 \\
\hline El Salvador & & 5.1 & 12.0 \\
\hline Brazil & & 4.7 & 7.1 \\
\hline Guatemala & & 4.5 & 11.3 \\
\hline Costa Rica & & 3.3 & 7.9 \\
\hline Panama & & 3.1 & 4.5 \\
\hline Nicaragua & & 1.8 & 11.1 \\
\hline Simple & age & 5.1 & 8.7 \\
\hline
\end{tabular}

$\nabla /$ The information contained in this table refers to those countries that privatized before 1998. $\diamond /$ This refers to the year when control of state's major stake was transferred to private hands. Source: ITU Database Indicators (1997a) and author compilation.

What overall effects might the privatization reform have had on the deployment of main phone lines per 100 inhabitants? Table 3 shows the simple (not weighted) average growth rate of main lines per 100 inhabitants. Prior to privatization, the average growth rates were very close when comparing those countries that later privatized and those that did not. However, it seems that after privatization the growth rate of 
teledensity for the countries that embarked on ownership reform grew much more rapidly than in countries that kept their (main) phone operators in public hands. This is still true even if we do not include the most recent privatization cases (Peru and Bolivia in Table 3). The statistical evidence seems to show that the privatization process tends to improve that performance measure. ${ }^{8}$ Here, we do not address which elements of the privatization process influenced the deployment of main lines per 100 inhabitants in the region.

Recently, scholars in telecommunications (see Petrazzini 1997) have pointed out the paradox of the regulatory mandate: the trend toward deregulation of the sector in developed countries and calls for a strong, independent, industry-specific regulatory agency in developing countries. Several arguments support the need for regulation. It is asserted that since utility industries have economies of scale and scope, the few players present in the market will exercise market power to the extent that a regulatory agency is needed as a check. It is also noted that there exist scarce resources in telecommunications, like the electromagnetic spectrum, that cannot be left to market forces alone. Again, a regulatory body is needed. Lastly, most countries in the region have privatized their former public telecom operator (PTO), and most governments conceded an exclusivity period to the new private owners. A former state monopoly was transformed into a private one. Hence, a strong regulatory entity ought to constrain an incumbent's incentives to foreclose entry or to engage in anticompetitive behavior during the post-exclusivity period.

To characterize regulatory development in telecommunications, we have constructed a dichotomous index showing the degree to which the regulatory framework in telecommunications affords (1) enforcement power to regulators and (2) neutrality/independence. In general, analysts of the sector have stressed additional characteristics that a regulatory body ${ }^{9}$ should have, like transparency, predictability and accountability among others. ${ }^{10}$ Note that the zero-one dummy variable should not be viewed as increased regulation, but as signaling

\footnotetext{
${ }^{8}$ We say "seems" because a simple test of means difference shows that post-privatization averages are different at a $5 \%$ significance level (one tail) but failed at higher significance levels.

${ }^{9}$ Regulatory body is defined as whatever individual, board or administrative agency makes decisions on regulatory matters.

${ }^{10}$ The paper by Galal and Nauriyal (1995) provided the initial basis for construction of our index. Additional relevant
} 
the existence of an independent regulator. This institutional innovation represents a major step for countries in the process of liberalizing the telecommunications sector. Although two characteristics (enforcement power and autonomy) have been identified through published studies, the variable might best be viewed as a proxy for serious reform initiatives (including reduction of entry barriers and privatization). Because of the wide range of liberalization strategies in the region (and the limited number of years of observations) we have not attempted to classify the different types of regulatory regimes. We recognize that incentive programs (including system expansion targets), exclusivity periods, rate-rebalancing initiatives, and X-factors for price caps, can all have differential (and sometimes counteracting) impacts on main-lines per capita. Without a larger database, we basically collapse these reform elements into a single index, a proxy for regulatory governance (Stern and Holder 1999). Regulatory incentives also influence sector performance. In addition, there is no doubt that competition can provide powerful pressures for improved sector performance, as noted in a number of studies, including Ros (1999).

Later we do introduce one variable, cellular subscribers per 100 inhabitants, to capture the role of competition from an alternative technology, but much more work needs to be done on the role of exclusivity periods and entry conditions (including interconnection prices). The degree of public ownership is another variable that warrants attention, since some countries have chosen to phase in privatization while others decided that a strategic investor would be better able to introduce new managerial techniques leading to improvements in service quality and cost containment. The nature of the privatization process is another issue that deserves more intensive investigation. With additional years of data, we can expect more complete specifications of the cause and effect of different types of reform initiatives.

To this point in our research, we used those characteristics noted above, assigning a zero value for those frameworks that lack them and 1 otherwise. There is some degree of subjectivity in the index, given the

literature includes ITU (1993), Tyler and Bednarczyk (1993), Miller (1994), Schultz (1994), Sinha (1995), Tenenbaum (1996), Petrazzini (1997), Armstrong and Vickers (1996), Cave (1997), Melody (1997b), Stern and Holder (1999) and Wellenius (1999). 
way it was constructed. ${ }^{11}$ However, this simple index allows us to utilize a larger sample of countries in our quantitative work. As far as we are aware, this is the first work that attempts to capture the role of regulation.

Although some countries in the region started the ownership reform in the late 1980s, we refrain from introducing privatization as an independent variable because we want to isolate the effects of the institutional and regulatory framework on network deployment. It is clear that privatization has been a factor that drove the enhancement of the telecommunications network in the region. Readers interested in some previous results can refer to Gutierrez (1999).

In the United States, researchers have reached important conclusions regarding the apparent positive and strong effects of incentive regulation on investment in the telecommunications sector. Specifically, Greenstein et al. (1995), Donald and Sappington (1995), Greenstein and Spiller (1995) and Donald and Sappington (1997) found that incentive regulation like price-cap regulation tends to have a bigger impact on investment in telecommunications than rate-of-return regulation. However, as Berg and Foreman (1996) and Kridel et al. (1996) warn, the links between the regulatory regime and telco performance are complex, so studies need to avoid pitfalls and must be carefully interpreted. Lack of reliable data also limits the chance of including pricing regimes as determinants of either network deployment or productivity for our sample of Latin American countries.

\section{Recent Empirical Studies}

Telecommunications reform in Latin America has attracted the attention of policy analysts. Most empirical studies about telecommunications reform in Latin America have thus far been limited to a few countries that privatized (totally or partially) their former public telecom operators. ${ }^{12}$ Some recent econometric

\footnotetext{
${ }^{11}$ The index was constructed by using information provided by telecommunications analysts in 19 countries. If, in the opinion of the analysts, the characteristic was present, we assigned a 1, zero otherwise. The number of analysts varies from country to country, making the index severely dependent on the number of analysts and their biases. In another study, Gutierrez (1999) began construction of a second-generation index to address this shortcoming and to include more features of the regulatory environment.

${ }^{12}$ It is not our purpose to review these works in detail. The more outstanding ones are: a) Ramamurti (1996), who analyses the privatization process in Argentina, Jamaica, Mexico and Venezuela; b) Molano (1997), who studies the
} 
studies have tried to explain partial telecommunications reforms or the effects of political and institutional variables on network deployment. Henisz and Zelner (1997) and Henisz (1998) explored how the political environment determined the long-run level of penetration of basic telecommunications infrastructure in 59 countries during 1975-92. Their variable for political constraints (a proxy for political checks and balances that limit policy changes) showed a strong and positive relationship with the number of main lines per 100 inhabitants. The economic and demographic variables were significant and with their expected signs.

Canning (1998) ran regressions that related stocks of infrastructure to demographic (population, land area, level of urbanization) and economic (per capita domestic product) variables. For a total of 79 countries around the world in the period 1965-95, he found that the growth rate of telephone main lines, although negatively associated with the area, was positively associated with the growth of GDP per capita, population and change in the urbanization ratio. Canning did not include any institutional or political variables, nor did he consider regulatory variables.

Lee (1999) examined how and to what extent social and institutional endowments ${ }^{13}$ affect network expansion and efficiency (measured as number of employees per 100 lines) in the Asia-Pacific region. ${ }^{14}$ Using panel data analysis, he found that the performance of telecommunications is positively related with better and sound macro-regulatory procedures. Furthermore, privatization of former state-owned operators results in higher efficiency as well as higher network expansion.

In a working paper, Wallsten (1999) analyzed telecommunications reform for a sample of countries in

effects of micro and macro variables on telecommunications in the Southern Cone of Latin America (Argentina, Brazil, Chile and Uruguay); c) Adam et al. (1992), who briefly review the cases of Jamaica and Trinidad and Tobago; d) Levy and Spiller (1996), who thoroughly study the regulatory process in Argentina, Chile, and Jamaica; e) the five studies on Latin America contained in the book edited by Wellenius and Stern (1994); f) Petrazzini (1996), who analyzes the cases of Argentina and Mexico; and g) Galal et al. (1994), who examine the welfare effects of privatized telecom operators in Chile and Mexico. These studies and a few more helped in the construction of a second-generation index of regulatory framework for 24 Latin American countries. For more details, see Gutiérrez (1999). More recently, Wellenius (1999) analyzed recent telecommunications reforms in Spanish-speaking Latin American countries.

${ }^{13}$ To control for the institutional environment, Lee uses the ICRG variable popularized by the studies of Knack and Keefer (1995) and Keefer and Knack (1997).

${ }^{14}$ The countries included in his sample are: Australia, Bangladesh, China, Hong Kong, India, Indonesia, Japan, Korea, 
Africa and Latin America. As we do, he tested how and to what extent variables like privatization, competition and regulation may have affected network expansion from 1984 to 1997. Using a fixed-effect model, he found that competition impacts main line penetration positively, but that privatization is negatively associated with such penetration, although not statistically significant. Regulation alone is negatively and significantly associated with network expansion. When Wallsten made competition and privatization interact with the regulatory variable, he found that both of them affect the level of main line penetration positively.

Although, Wallsten's research is a useful addition to the study of telecommunications reform, in our opinion it suffers from one main shortcoming. He combines countries in two very dissimilar areas: Africa and Latin America. Even across Latin America, there is a lot of different institutional and cultural development that one needs to control for. Furthermore, to measure competition, Wallsten uses the number of cellular companies in a country. This is a misleading indicator; cellular customers per 100 citizens gives a better indication of pressure from spectrum technology. ${ }^{15}$

Ros (1999) presents an econometric analysis of the effects of ownership and competition on main lines per 100 inhabitants and the growth rate in that variable for a sample of 110 countries around the world. His main results are that ownership (or privatization) is positively related to the main lines variable and with its growth rate. Competition, however, seems to have no effect on network expansion. The work of Ros clarifies some effects of telecommunications reform but does not explain at all the effect that regulation may have had on telecommunications performance. As he mentions (1999, p. 72, italics added), "Regulation plays an important role that affects a firm's efficiency.... As such, it is important to attempt to control for the type of regulation that the newly privatized firms are exposed to.... While all these factors are important theoretical

Malaysia, New Zealand, Pakistan, the Philippines, Singapore, Sri Lanka and Thailand.

${ }^{15}$ All Latin American countries are divided into separate regions using what is called Band A and Band B. The main difference between these two bands is the frequency on which cellular operators are allowed to provide service. For instance, in Chile, Band A transmission frequencies go from 825.030 to $834.990 \mathrm{MHz}$, while Band B starts at 835.029 and goes to $855.980 \mathrm{MHz}$. The frequencies vary from country to country, depending on the availability of frequencies. In essence, at least in Latin America, the cellular markets are duopolistic in the sense that cellular operators in a region cannot legally provide telecommunications services other than in their own markets. A cellular user wanting to call to a different region has to use a long distance operator. 
determinants of network expansion and efficiency, data constraints prevented them from being formally modeled below. As a result, any conclusions obtained below must take this into account."

Again, as in the case of Wallsten's study, Ros mixes developed and developing countries, and countries that have and have not privatized their operators. There is a lot of heterogeneity in his sample. Even running regressions for countries with GDP per capita below U.S. $\$ 10,000$ may not reduce the level of heterogeneity and thus limits the scope of his conclusions.

Using panel data techniques, Gutierrez (1999) finds that the regulatory framework index is always positively associated with the level of network deployment and the efficiency level. Those countries where regulatory reform has been furthered showed significantly higher levels of main lines per 100 inhabitants, no matter their income level. Also, those countries that have allowed competition in basic telecommunications services had more main lines per 100 inhabitants and better efficiency level. Privatization tends to be positively associated with those two variables. However, privatization is not associated positively with network deployment and efficiency for countries whose average GDP per capita is lower than U.S. \$1,500.

Recently, Hamilton (2000) examined the effect of relevant demographic, economic, political, institutional and competitive factors on investment in basic telecommunications in Africa. Her paper is a first step in exploring the effects of certain institutional political and competitive factors on the performance of basic telephony in Africa. She found that a strong institutional framework in which investors are guaranteed property rights, reduced risk of expropriation, and credible contractual security is associated with improved telecom performance. High per capita GDP is also associated with improved performance, but by itself is not as strong as expected. However, data limitations prevented an analysis of regulatory institutions.

In another contribution to the literature, Ros and Banerjee (2000) study the effects of privatization and tariff re-balancing for a sample of 23 Latin American countries during the period 1986-95. Their main results are that privatization affects expansion and efficiency in a significantly positive way. Their paper also sheds some light about the effects of tariff re-balancing on excess demand. They found a negative relationship between those two variables. 
6. Variables, Data and Econometric Model

In this study, we analyze the determinants of the penetration level of lines in 19 Latin American countries. For our purposes, the main lines installed per 100 inhabitants, our dependent variable, will be the proxy for the level of investment in the telecommunications sector. ${ }^{16}$ Although the sector is comprised of many different kinds of operators (e.g., long distance operators, local phone companies, and value-added service providers), the measure provides an adequate first-approximation of telecom investment.

First, to approach the regulatory governance in telecommunications, we use the dichotomous index of regulatory development explained in Section 4 above. A positive relationship is expected between the level of investment and this index: the more enforcement power and neutrality are present in the regulatory body, the more investment will be undertaken by private investors (as well as by public managers, who also want to avoid investing in risky settings).

As we said before, the regulatory index should be viewed as the existence of a regulatory framework for the telecommunications sector. However, statistical tests showed correlation between the index and the error term, suggesting that the regulatory index variable is endogenously determined. Subsequently, the instrumental variable technique was applied. Following Heckman (1978, p. 947), we estimated the probability of the existence of a regulatory body in a country in a given year. A logit model was run, including as regressors the exogenous variables in our main equation below. Then, the predicted probabilities from the logit were interacted with the observed dichotomous values of our regulatory index and used as the instrument in a two-stage dummy-variable model that includes dummies to control for country-specific effects.

Although the regulatory framework for telecommunications is important, other aspects of the overall institutional environment of a country must be included. As North stresses, the existence of a strong polity is needed to keep the institutions working. We approach polity from the perspective of the political stability a

\footnotetext{
${ }^{16}$ Once again, we warn readers that our proxy of investment main lines per 100 inhabitants refers only to investment in basic telephony (local and long distance telephony). The data on investment in the telecommunications sector for the Latin American countries reported to the ITU is poor and almost incomplete for most of the countries. This explains our choice of main lines as a proxy for investment.
} 
government can have. We make use of Jaggers and Gurr's measure of democracy (1995), which came from the Polity III database. Numerous studies have considered the effect of political (in)stability and property rights on economic growth and accurate ways to ascertain the level of democracy (see, for example, Barro 1996, 1998; Clague et al. 1996; Haan and Siermann 1995; Helliwell 1994; Przeworski and Limongi 1993; Alesina and Perotti 1996; and Londregan and Poole 1996). Although we should expect a positive relationship, the relationship between measures of democracy and economic growth or reforms is much more complex, so conclusive results may not be possible.

The number of cellular subscribers is another independent variable affecting the number of lines per person. Cellular represents a competitive threat to wire-line telephony (Smith 1996), as a substitute. However, it could be a complement having a positive affect on the demand for telephone lines. Complicating the interpretation of the role of this variable is the possibility that the competitive threat represented by spectrum technology actually stimulates incumbent investment in wire-line facilities.

Gwartney et al. (1999) recently introduced a measurement of economic freedom that tries to capture the degree to which citizens and investors enjoy freedom within a country. The developers of the index believe that more open economies that rely on market processes, treat individuals equally, and keep sound monetary policy will attract more foreign investors and have a greater level of investment and economic growth. (For more detailed information, see Gwartney and Lawson 1997.) Hence, in addition to the regulatory and political variables, we include the economic freedom index as a potential explanatory variable. We expect a positive relationship between that index and the penetration level.

Finally, as Sappington (1993, p. 256) states, "Institutions clearly matter...but other factors, such as consumer income and preference, objectives of regulators, population density, and other determinants of the firm's cost structure affect optimal regulatory policy." Hence, we control for economic and demographic variables. Two economic variables are used: GDP per capita (a proxy for income effects) and the level of openness of the economy (measured as the sum of exports and imports as a percentage of GDP). These 
measures are expected to have a positive impact on investment. Among the demographic variables, we introduce population density, inhabitants per square kilometer. This variable is a proxy for cost variables. The more densely populated an area, the lower the cost of extending a wire-line telecommunications network and the higher the level of investment.

Because of the limited availability of data for the Economic Freedom Index, annual data on main lines installed per 100 inhabitants covering 19 Latin and Caribbean countries are used in this study for the three years 1986, 1990 and 1995. Thus, the sample consists of a maximum of 57 observations. The data are divided into three categories, with the equation to be estimated given as follows:

$$
\begin{gathered}
\text { MLINES }_{i t}=\alpha+X_{I^{\prime}} \beta_{1}+X_{2^{\prime}} \beta_{2}+X_{3^{\prime}} \beta_{3}+\mu_{i t}, \text { where } \\
u_{i t}=\mu_{i}+v_{i t} \\
X_{1}=\left[\operatorname{GDPPC}_{i t}, \text {TRADE}_{i t}\right] \\
X_{2}=\left[\operatorname{POPDEN}_{i t}\right] \\
X_{3}=\left[\text { EFREEI }_{i t}, \text { TREGUL }_{i t}, \text { GOVTYPE }_{i t-1}\right]
\end{gathered}
$$

where $i=$ country, $t=$ time and where:

MLINES : $\quad$ Main phones lines installed per 100 inhabitants

GDPPC: $\quad$ GDP per capita in U.S. $\$ 1990$

TRADE: $\quad$ Sum of exports plus imports over GDP

POPDEN: Population per square $\mathrm{km}$.

CELLSUB Cellular subscribers per 100 inhabitants

EFREEI: $\quad$ Economic Freedom Index

TREGUL: Regulatory framework index in telecommunications (It takes value a value of 1 if the regulatory body has the main characteristics and 0 otherwise.)

GOVTYPE: Democracy index constructed according to Jaggers and Gurr (1996) 
$\mu_{\mathrm{i}}: \quad$ Non-observable characteristics of each country,

$v_{i t}: \quad$ Denotes the remainder disturbances.

\section{Results}

The results obtained by using a panel data consisting of time series and cross section are reported in Table 4. The results in column (1), (2), and (3) differ only in the number of explanatory variables.

Summary statistics for our data set (equation 3) appear in the Appendix, Tables 1A and 2A.

\begin{tabular}{|c|c|c|c|c|}
\hline & (1) & (2) & (3) & $\begin{array}{l}\text { (4) Correcting for } \\
\text { Endogeneity } \bullet\end{array}$ \\
\hline \multirow[t]{2}{*}{ POPDEN } & & $.073 *$ & $.073^{*}$ & $0.068^{*}$ \\
\hline & & (1.61) & (1.69) & (1.64) \\
\hline \multirow[t]{2}{*}{ GDPPC } & $.558-02 * * *$ & $.176-02 * *$ & $.176-02 * *$ & $.114-02 * * *$ \\
\hline & $(4.53)$ & $(2.06)$ & $(2.16)$ & (3.16) \\
\hline \multirow[t]{2}{*}{ TRADE } & $.673-04 * * *$ & $.650-07$ & & \\
\hline & $(3.11)$ & $(.469-02)$ & & \\
\hline \multirow[t]{2}{*}{ CELLSUB } & & $3.01 * * *$ & $3.01 * * *$ & $3.06 * * *$ \\
\hline & & $(5.55)$ & $(6.54)$ & $(7.09)$ \\
\hline \multirow[t]{2}{*}{ GOVTYPE } & & $.370 *$ & $.371^{*}$ & $.516^{* *}$ \\
\hline & & (1.73) & (1.77) & (2.39) \\
\hline \multirow[t]{2}{*}{ EFREEI } & & .373 & $.374^{*}$ & .152 \\
\hline & & (1.59) & $(1.71)$ & $(0.9)$ \\
\hline \multirow[t]{2}{*}{ TREGUL } & & $1.26^{* *}$ & $1.26^{* *}$ & $2.25 * * *$ \\
\hline & & (1.97) & $(2.01)$ & $(2.56)$ \\
\hline Adj. $R^{2}$ & .8188 & .9525 & .9540 & .9520 \\
\hline F-test & $F(18,36)=5.99$ & $\mathrm{~F}(18,31)=12.1$ & $\mathrm{~F}(18,32)=12.9$ & \\
\hline $\begin{array}{c}\mathrm{N} \\
\text { (mean) }\end{array}$ & $\begin{array}{c}57 \\
19 \text { Countries }\end{array}$ & $\begin{array}{c}57 \\
19 \text { Countries }\end{array}$ & $\begin{array}{c}57 \\
19 \text { Countries }\end{array}$ & $\begin{array}{c}57 \\
19 \text { Countries }\end{array}$ \\
\hline
\end{tabular}

Note: The number in parentheses under coefficient estimates is the t-statistic.

* Means significantly different from zero at the $10 \%$ level.

** Means significantly different from zero at the $5 \%$ level.

*** Means significantly different from zero at the $1 \%$ level.

/ Teledensity as a proxy of investment.

-/ Coefficients for dummy variables for country-specific effects not shown. 
We select column (4) to explain the main results. First, comparing equation (4) to equation (1), we note an increase in the overall explanatory power of the model. The adjusted R-square increases from $81.9 \%$ to $95.2 \%$, indicating that the institutional and regulatory variables do help explain the level of investment in telecommunications. Second, it is evident that almost all regressors are statistically significant at conventional levels and have the expected sign. That is, a sound institutional endowment consisting of a strong telecom regulatory body and a stable political system increase the level of main lines per 100 inhabitants. Although the economic freedom index was not statistically significant, it does have the expected sign, showing that economic freedom and our proxy of investment in telecommunications are positively related.

Since the units of variables are not comparable, standardized estimates of their regression coefficients need to be calculated. These new estimates show the change in the dependent variable, in standards deviation units, for a one-unit change in the standard deviation of the independent variable. We illustrate the calculation in three steps: (1) a one-standard-deviation increase (an improvement) in the Economic Freedom Index is associated with an increase in the main lines by $20.7 \%$ of its standard deviation (obtained by multiplying 0.152 , the slope coefficient, by 1.36 , the standard deviation of the index); (2) the standard deviation of the dependent variable, main lines per 100 inhabitants, is 4.52 lines per 100 inhabitants; (3) these indicate that an increase of one standard deviation in EFREEI increases the penetration rate by about 1 line per 100 inhabitants (4.5 times .207). Using this procedure, we find that an increase in the sum of a one-standard-deviation in the polity, the EFREEI and in the regulatory index increases altogether the penetration rate by 8.8 main lines per 100 inhabitants. For comparison purposes, recall that the (unweighted) mean penetration rate for 1985-95 is 6.76 lines (Appendix-Table 2).

Another way to visualize the result is as follows. If a country close to the average level of the economic freedom index (5.14) for the three-year sample, such as Jamaica (5.13) or El Salvador (5.23), were to improve the quality of its economic freedom by one standard deviation to reach a level a little higher than that of Uruguay (6.4), its phone penetration rates would increase by one line per capita.

Another important explanatory variable is the number of cellular phones per 100 inhabitants 
(CELLSUB). This variable has a positive impact on lines per capita, which could reflect a "competition effect" whereby competitive entrants stimulate improved performance and additional investment by (public and private) wire firms.

The economic variable GDPPC is significant and has the expected sign. The positive income effect is consistent with findings in other studies. Although TRADE has the expected sign, it is not significant at any conventional level. The possible explanation for this may be the fact that trade reform in most countries had just started in the early 1990s. Its impact is weak but in the right direction. ${ }^{17}$

\section{CONCLUSIONS}

The ranking of the impact of each of the explanatory variables on the penetration rate is shown in Table 5. As expected, the economic (income) and demographic (cost) variables have a greater impact on our proxy of investment in telecommunications. However, the regulatory (institutional) and political factors may have been an important driving force behind the surge of modernization in the sector. The results serve as a signal to governments regarding the importance of well-functioning political and regulatory institutions.

Table 4

Impact of Explanatory Variables on Teledensity

\begin{tabular}{|l|c|c|}
\hline Variable & A one-standard deviation impact*/ & Increase in Teledensity*/ \\
\hline POPDEN & 2.89 & 13.10 \\
\hline GDPPC & 1.45 & 6.57 \\
\hline CELLSUB & 1.36 & 6.13 \\
\hline GOVTYPE & 0.78 & 3.53 \\
\hline TREGUL & 0.95 & 4.30 \\
\hline EFREEI & 0.207 & 0.93 \\
\hline
\end{tabular}

*/Taking the results of column 4 , Table 3 .

Clearly, this empirical study calls for extensions. The availability of more data (see Gutiérrez 1999)

\footnotetext{
${ }^{17}$ We should note that the sample period might not be long enough to capture the effect of trade reform. Recall that some analysts of Latin America's performance are not satisfied with the growth rate in GDP in recent years (see IADB 1997).
} 
will permit a more comprehensive analysis of telecommunications reform. In addition the effects of privatization warrant greater attention. By pooling annual observations and dropping variables for which limited data are available, other models can be tested. Also, the dynamics of demonstration effects across countries could be explored. Do policies adopted by neighbors and their telecommunications performance affect the timing of national infrastructure policy initiatives? Most important, national policy is endogenous: privatization, the creation of regulatory agencies, and the promotion of competition (via cellular or wire line) arise because of past policy failures and poor industry performance. So more complicated (simultaneous, lagged) models need to be specified and tested (Berg and Foreman 1996). Nevertheless, this initial study sheds new light on the determinants of telecommunications investment in the region.

\section{REFERENCES}

Adam, Christopher, William Cavendish and Mistry Percy. 1992. Adjusting Privatization: Case Studies from Developing Countries. London: James Currey.

Alesina, Alberto, and Roberto Peroti. 1996. "Income Distribution, Political Instability, and Investment," European Economic Review 40: 1203-28.

Armstrong, Mark, and John Vickers. 1996. "Regulatory Reform in Telecommunications in Central and Eastern Europe," Economics of Transition 4: 295-318.

Barro, Robert. 1996. “Democracy and Growth,” Journal of Economic Growth 1: 1-27. 1999. “Determinant of Democracy,” Journal of Political Economy 107: S158-S183.

Berg, Sanford, and Dean R. Foreman. 1996. "Incentive Regulation and Telco Performance: A Primer," Telecommunications Policy, October,20: 641-652.

Campos, Nauro, and Jeffrey Nugent. 1998. "Instituciones y Crecimiento. Puede el Capital Humano ser el Vinculo?" Revista de la Cepal 64: 7-27.

Canning, David. 1998. "A Database of World Stocks of Infrastructure, 1950-1995," The World Bank Economic Review 12: 529-47.

Cave, Martin. 1997. "New Developments in Telecommunications Regulation." In The New Research Frontiers of Communications Policy, edited by Donald Lamberton, pg. \#s. Amsterdam: Elsevier. 
Clague, Christopher, Phillip Keefer, Stephen Knack and Mancur Olson. 1996. "Property Rights in Autocracies and Democracies," Journal of Economic Growth 1: 243-76.

Donald, Stephen and David Sappington (1997), "Choosing among Regulatory Options in the United States Telecommunications Industry", Journal of Regulatory Economics 12: 227-243

and (1995), "Explaining the Choice among Regulatory Plans in the U.S. Telecommunications Industry", Journal of Economics and Management Strategy 4: 237-265.

Easterly, William, Norman Loayza and Peter Montiel (1997) "Has Latin America's post-reform growth been disappointing?” Journal of International Economics 43: 287-311.

Fernandez-Arias, Eduardo, and Peter Montiel. 1997. Reform and Growth in Latin America: All Pain, No Gain? OCE Working Paper No 351. Washington, D.C.: Inter-American Development Bank.

Greenstein Shane and Pablo Spiller (1995), "Modern Telecommunications Infrastructure and Economic Activity: An Empirical Investigation," Industrial and Corporate Change. 4: 647-665.

Greenstein Shane, Susan McMaster and Pablo Spiller (1995), "The Effect of Incentive Regulation on Infrastructure Modernization: Local Exchange Companies' Deployment of Digital Technology," Journal of Economics and Management Strategy, 4: 187-236.

Galal, Ahmed, Leroy Jones, Pankaj Tandon and Ingo Vogelsang. 1994. Welfare Consequences of Selling Public Enterprises: An Empirical Analysis. Washington, D.C.: The World Bank.

, and Bharat Nauriyal. 1995. "Regulation of Telecom in Developing Countries: Outcomes, Incentives and Commitment," Revista de Análisis Económico 10: 41-62.

Gonzalez, Adrian E., Amar Gupta and Sawan Deshpande. 1998. "Telecommunications in Mexico," Telecommunications Policy 22: 341-57.

Gutiérrez, Luis H. 1999. "An Index of Telecommunications Regulatory Frameworks in the Context of Privatization and Competition Reform." Ph.D.dissertation, University of Florida, Gainesville.

Gwartney, James, and Robert Lawson. 1997. Economic Freedom of the World: 1997 Report. Vancouver: Fraser Institute.

, Robert Lawson and Randall Holcombe. 1999. "Economic Freedom and the Environment for Economic Growth,” Journal of Institutional and Theoretical Economics 155: 643-63.

Haan, Jacob De, and Clemens Siermann. 1995. "New Evidence on the Relationship between Democracy and Economic Growth," Public Choice 86: 75-198.

Hamilton, Jackie. 2000. "Institutions, Competition and the Performance of Telecommunications Infrastructure in Africa," PURC working paper, University of Florida, Gainesville.

Helliwell, John F. 1994. "Empirical Linkages between Democracy and Economic Growth," British Journal of Political Science 24: 225-48. 
Henisz, Witold, 1998. "The Institutional Environment for International Investment: Safeguarding against State Sector Opportunism and Opportunistic use of the State" Ph.D. dissertation, University of California at Berkeley.

and Bennet A. Zelner, 1997. "The Institutional Determinants of Infrastructure Growth in Telecommunications: a Cross-National Study," Telecommunications Policy Research Conference Paper, September: 1-51.

Hudson, Heather E. 1997. Global Connections: International Telecommunications Infrastructure and Policy. New York: Van Nostrand Reinhold.

Inter-American Development Bank. 1997. Latin America After a Decade of Reforms, Economic and Social Progress in Latin America, 1997 Report. Washington, D.C.:IADB.

International Telecommunications Union. 1993. The Changing Role of Government in an Era of Deregulation. ITU Regulatory Colloquium No 1. Geneva: ITU.

1997a. ITU Database World Telecommunications Indicators 1997. Geneva:ITU.

1997b. World Telecommunication Development Report 1996/97, Trade in Telecommunications, Geneva:ITU.

Jaggers, Keith, and T Robert Gurr. 1995. "Tracking Democracy's Third Wave with the Polity III Data," Journal of Peace Research 32: 469-82.

and . 1996. "Polity III: Regime Change and Political Authority, 1800-1994," $2^{\mathrm{ND}}$ ICPSR version [computer file]. Ann Arbor: Inter-university Consortium for Political and Social Research.

Knack, Stephen, and Phillip Keefer. 1995. "Institutions and Economic Performance: Cross-country Tests Using Alternative Institutional Measures," Economics and Politics 7: 207-27.

Keefer, Philip, and Stephen Knack. 1997. "Why Don't Countries Catch Up? A Cross-National Test of an Institutional Explanation,” Economic Inquiry 35: 590-602.

Kridel, Donald, David Sappington and Dennis Weisman (1996), "The Effects of Incentive Regulation in the Telecommunications Industry: a Survey", Journal of Regulatory Economics 9: 269-306.

Lee, Sang Hyup. 1999. "Effects of Institutional Endowments on the Performance of the Telecommunications Sector: Evidence from Asia-Pacific Countries." Ph.D. dissertation, University of Florida, Gainesville.

Levy, Brian, and Pablo T. Spiller. 1996. Regulations, Institutions, and Commitment: Comparative Studies of Telecommunications. New York: Cambridge University Press.

Londegran, John, and Keith Poole. 1996. “Does High Income Promote Democracy?” World Politics 49: 1-30.

Lora, Eduardo. 1998. "Una Decada de Reformas Estructurales en America Latina: Que se ha reformado y Como medirlo," Pensamiento Iberoamericano, Volumen Extraordinario: 27-53. 
and Felipe Barrera. 1997. A Decade of Structural Reform in Latin America: Growth, Productivity, and Investment Are Not What They Used to Be, OCE Working Paper No 350, Washington, D.C.: InterAmerican Development Bank

McCormick, Patricia K. 1993. "Telecommunications Privatization Issues: The Jamaican Experience," Telecommunications Policy 17: 145-57.

Melody, William H. 1997. "On the Meaning and Importance of 'Independence' in Telecom Reform," Telecommunications Policy 21: 195-99.

Miller, Nicholas. 1994. "Regulation: Reconciling Policy Objectives." In Implementing Reforms in the Telecommunications Sector: Lessons from Experience, edited by Björn Wellenius and Peter A. Stern. Washington D.C.: The World Bank.

Molano, Walter T. 1997. The Logic of Privatization: The Case of Telecommunications in the Southern Cone in Latin America. Westport, CT: Greenwood Press.

Noll, Roger G. 1999. Telecommunications Reform in Developing Countries, Working Paper 99-10. Washington, D.C.: AEI-Brookings Joint Center for Regulatory Studies.

North, Douglass C. 1990. Institutions, Institutional Change and Economic Performance. New York: Cambridge University Press.

Pastor, Manuel, and Eric Hilt. 1993. "Private Investment and Democracy in Latin America," World Development 21: 489-507.

Petrazzini, Ben A. 1996. "Telephone Privatization in a Hurry." In Privatizing Monopolies: Lessons from the Telecommunications and Transport Sectors in Latin America, edited by Ravi Ramamurti. Baltimore: John Hopkins University Press.

Petrazzini, Ben A 1997. "Regulating Communications Services in Developing Countries." In Telecom Reform: Principles, Policies and Regulatory Practices, edited by William Melody. Lyngby: Den private Ingeniørfond, Technical University of Denmark.

Pisciotta, Aileen A. 1997. "Global Trends in Privatisation and Liberalisation." In Telecom Reform: Principles, Policies and Regulatory Practices, ed. William Melody. Lyngby: Den private Ingeniørfond, Technical University of Denmark.

Przeworski, Adam, and Fernando Limongi. 1993. "Political Regimes and Economic Growth," Journal of Economic Perspectives 7: 51-69.

Ramamurti, Ravi. 1996. Privatizing Monopolies: Lessons from the Telecommunications and Transport Sectors in Latin America. Baltimore: John Hopkins University Press.

Ros, Agustin J. 1999. "Does Ownership or Competition Matter? The Effects of Telecommunications Reform on Network Expansion and Efficiency," Journal of Regulatory Economics 15: 65-92.

and Aniruddha Banerjee. (2000) "Telecommunications Privatization and Tariff Rebalancing: 
evidence from Latin American" Telecommunications Policy 24: 233-252.

Sappington, David. 1993. “Comment on 'Regulation, Institutions, and Commitment in Telecommunications' by Levy and Spiller, " Proceedings of the World Bank Annual Conference on Development Economics. Washington, D.C.: The World Bank.

Schultz, Richard J. 1994. "Regulation and Telecommunications Reform: Exploring the Alternatives." In Implementing Reforms in the Telecommunications Sector: Lessons from Experience, edited by Björn Wellenius and Peter A. Stern. Washington D.C.: The World Bank.

Sinha, Nikhil. 1995. "Regulatory Reform: An Institutional Perspective." In Telecommunications Politics: Ownership and Control of the Information Highway in Developing Countries, edited by Mody et al. Malwah, NJ: Lawrence Erlbaum.

Smith, Peter L. 1996. "End of the Line for the Local Loop Monopoly?" Private Sector Infrastructure. Washington, D.C.: The World Bank Group.

, and Bjorn Wellenius. 1999. "Mitigating Regulatory Risk in Telecommunications." Note No. 189 in Public Policy for the Private Sector. Washington, D.C.: The World Bank Group.

Spiller, Pablo. 1993. "Institutions and Regulatory Commitment in Utilities' Privatization," Industrial and Corporate Change 2: 387-450.

Stern, Jon, and Stuart Holder. 1999. "Regulatory Governance: Criteria for Assessing the Performance of Regulatory Systems: An Application to Infrastructure Industries in the Developing Countries of Asia," Utilities Policies 8: 33-50

Stiglitz Joseph E. 1998. "More Instruments and Broader Goals: Moving toward the Post-Washington Consensus." Presented January 7 as the WIDER Annual Lecture at the World Institute for Development Economics Research, Helsinki.

Tenenbaum, Bernar. 1996. "Regulation: What the Prime Minister Needs to Know," Electricity Journal 13: 28-36.

Tyler, Michae,l and Susan Bednarczyk. 1993. "Regulatory Institutions and Processes in Telecommunications: An Alternative Study of Alternatives," Telecommunications Policy 17: 650-76.

Wallsten, Scott J. 1999. "Competition, Privatization, and Regulation in Telecommunications Markets in Developing Countries: An Econometric Analysis of Reforms in Africa and Latin America." mimeograph.

Wellenius, Björn, and Peter Stern. 1994. Implementing Reforms in the Telecommunications Sector, Washington DC: The World Bank.

Wellenius, Björn. 1999. "Regulating the Telecommunications Sector: The Experience of Latin America." In Regulatory Policy in Latin America: Post-privatization Realities, edited by Luigi Manzetti. Miami: NorthSouth Center Press. 
Williamson, Olive. 1975. Markets and Hierarchies, Analysis and Antitrust Implications. New York: The Free Press. 


\section{APPENDIX}

\section{Source of the Variables.}

MLINES (or teledensity) is main lines: each line represents "a telephone connecting the subscriber's terminal equipment to the public switched network" and has a dedicated port in the telephone exchange equipment. It is derived by taking (Main Lines/Population) *100. It is taken from the International Telecommunications Union (ITU).

The economic variables: GDPPC is the GDP per capita in 1990 U.S. dollars; TRADE is the ratio (export plus imports)/GDP. Both variables are taken from the IADB Social and Economic Database (Inter-American Development Bank).

The demographic variable POPDEN, population density, is taken from the World Bank, "Economic and Social Indicators CD-ROM".

The GOVTYPE index was constructed by using the data provided by Jaggers and Gurr's (1996) Polity III. We follow Londregan and Poole (1996) and combine the two measures of DEMOC and AUTOC to construct GOVTYPE. GOVTYPE = DEMOC - AUTOC. This raw measure creates a 21-point scale with a floor of -10 , and a ceiling of 10. Applying the logistic transformation to it, we get $T(S)=\ln (S+10.5)-\ln (10.5-\mathrm{s})$. This converts scores to a truly continuous scale. A value of $S$ at 10.5 would correspond to a $T(S)$ of $\infty$; an $S$ of -10.5 corresponds to a $\mathrm{T}(\mathrm{S})$ at $-\infty$.

The EFREEI is published by the Economic Freedom Network. The index is based on four major areas: (1) money and inflation, (2) structure of the economy, (3) takings and discriminatory taxes, and (4) international trade. The index we use is the simple sum of the four developed by Gwartney and Robert (1997). The index is available for 1980, 1985, 1990 and 1995. So we assume that for 1986, the EFREEI is lagged one period. This should not affect the results.

The TREGUL index is constructed by using information from papers, articles, essays, books, Internetdownloaded information and questionnaires sent to officials and regulators in some Latin American and Caribbean countries. The studies analyze privatization, regulatory framework, and telecommunications policy in each of the sample countries. More specifically, we focus on aspects regarding: the degree of independence of the regulatory body in telecommunications, enforcement powers, neutrality, and mechanisms for conflict resolution. The index was constructed in a dichotomous way: a 1 was assigned to those countries that have all or most of the above characteristics and zero otherwise. Given that the literature from which this index was constructed is substantial, the interested reader can refer to Gutierrez's (1999) dissertation for details.

The CELLSUB variable is the number of cellular subscribers per 100 inhabitants, taken from the ITU database.

\section{TABLE 1A. Correlation Matrix*}




$\begin{array}{lllll} & \text { GDPPC } & \text { TRADE } & \text { POPDEN } & \text { TREGUL } \\ \text { GDPPC } & 1.0000 & & & \\ \text { TRADE } & -0.12493 & 1.0000 & & \\ \text { POPDEN } & 0.13764 & 0.33113 & 1.00000 & \\ \text { TREGUL } & 0.21306 & 0.17521 & 0.36098 & 1.00000 \\ \text { CELLSUB } & 0.27427 & 0.11180 & 0.09170 & 0.36344 \\ \text { EFREEI } & -0.09331 & 0.40103 & -0.03624 & 0.15956 \\ \text { BURQUA } & 0.41374 & -0.15890 & 0.12632 & 0.35977 \\ \text { GOVTYPE } & 0.17180 & -0.15007 & 0.23334 & 0.15488 \\ & & & & \\ \text { CELLSUB } & 1.00000 & \text { EFREEI } & \text { GOVTYPE } & \\ \text { EFREEI } & 0.19051 & & & \\ \text { GOVTYPE } & 0.25836 & 1.00000 & & \\ \text { * Variables are defined in Appendix } & -0.0394 & 1.00000 & \end{array}$

TABLE 2A. Summary Statistics for Variables Included in Regressions*

$\begin{array}{llllr} & \text { Mean } & \text { Std Dev } & \text { Minimum } & \text { Maximum } \\ \text { TELELIN } & 6.75614 & 4.52156 & 1.16000 & 19.5600 \\ \text { GDPPC } & 2124.01 & 1268.48 & 468.000 & 5983.00 \\ \text { TRADE } & 57.7638 & 35.1910 & 10.9154 & 162.338 \\ \text { POPDEN } & 36.0714 & 42.3274 & 2.86508 & 169.421 \\ \text { TREGUL } & 0.22807 & 0.42332 & 0.00000 & 1.00000 \\ \text { CELLSUB } & 0.22140 & 0.44358 & 1.00000 \mathrm{D}-10 & 1.80000 \\ \text { EFREEI } & 5.14211 & 1.36224 & 1.70000 & 7.10000 \\ \text { GOVTYPE } & 1.66795 & 1.51370 & -2.00148 & 3.71357\end{array}$

* refers to regressions 3 in Table 3.

Number of observations: 57. 